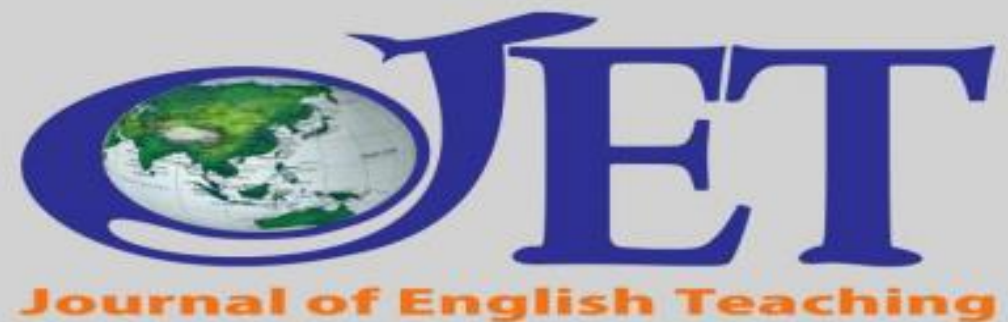

Volume 3, Number 2, June 2017

\title{
Improving the Eight Graders' Reading Comprehension through Jigsaw Technique at SMP 1 PSKD
}

\author{
Adelina Fransiska \\ Siska79adelina@gmail.com \\ SMP 1 PSKD, Jakarta
}

\begin{abstract}
The main objective of this research is to improve the eighth graders' reading comprehension through Jigsaw technique at SMP 1 PSKD. This research is a classroom action research in two cycles. The research was done on April 12th, 2016 until May 24th, 2016. The subject of the research was the students of VIII class at SMP 1 PSKD. There were 27 students (13 males and 14 females). The instruments of the test are pre-test and post-test. The non-test instruments were observation sheets, interview, and researcher's diary notes. The improvement of the eighth graders' reading comprehension scores can be seen from the result of the pre-test and post-test. The average score of the students in the pre-test was 49.03 points and in cycle 1 the average score of the students was 65.78 points. So the increase between the two tests was 16.75 or $34.16 \%$. In the cycle 2 , the average of students' score was 75.85 points. The result of the posttest 1 was 65.78 points, so the increase from post-test 1 in cycle 1 to post-test 2 in cycle 2 was 10.07 points or $15.75 \%$. The improvement from pre-test to post-test 2 was $54.70 \%$. In addition to the score increase, jigsaw technique can improve the students' enthusiasm in learning reading comprehension. It can be seen from the result of the interview. The participants were interested in learning reading comprehension through jigsaw technique because jigsaw technique helped them in comprehending the text. This research was also supported by the result of researcher's diary notes. The researcher's diary notes shows that there were a positive changed from cycle 1 to cycle 2 . Based on the results of the research, it can be concluded that jigsaw technique could improve the eighth graders' reading comprehension at SMP 1 PSKD.
\end{abstract}

Keywords: jigsaw technique, reading comprehension 


\section{Introduction}

Teaching reading is not easy. It requires motivation and creativity to establish conducive condition so that the students succeed in reading, particularly English text. In general, reading is still a big challenge for junior high school students. For example, when students read the text, they cannot comprehend it because the text is very long. For that reason, students need to improve their reading comprehension through an interesting technique.

Reading comprehension is assessed in National Examination for Junior High School. It has been done for many times ago. Reading test is the ability to comprehend text in written English. To pass the examination, students need to master reading comprehension. There are some reading kinds which are assessed in National Examination. They are procedure text, recount text, narrative text, descriptive text, and news item text. Basically, students have to know and comprehend those kinds of texts. In this sense, students must have good reading skills to pass the exam and fulfill the passing grade.

Based on the definition above, reading comprehension can be concluded as the ability to find the stated or unstated the writer's idea of the text. The essence of reading comprehension understands all information delivered by the writer. It also refers to connect between the words in a text and to understand the ideas. Based on the researcher's observation during teaching practice at SMP 1 PSKD, the main issue found in learning English for students was the lacked of reading comprehension. It was showed from the students' score. The researcher gave students a narrative text and assigned them to answer the questions. They did not know the answer and most of them earned low score. The factor of reading comprehension issue was the lacked of students' motivation and participation in reading. It means that the teacher should be aware of this situation. Teachers have to find a solution for this issue

Based on the explanation above, it is obvious that to improve the eighth graders' reading comprehension should be made the first priority. The researcher believes that jigsaw technique is a technique which may help the improvement of students' reading comprehension. Jigsaw technique is closely related to cooperative learning method. Cooperative learning method is a good method to use in classroom. Pierce (2015, p.2) mentioned, "Cooperative groups help students feel more comfortable asking questions to 
one another rather than asking in front of all of their peers". Cooperative learning helps students to be more active in classroom and more motivated to study English. As Meng (2010) found that jigsaw cooperative learning gives an advantage a classroom.

Realizing the effectiveness of jigsaw technique to improve eighth graders' reading comprehension, the researcher in this current study would like to see whether eighth graders' reading comprehension can significantly improved through jigsaw technique. Specifically, the study addressed the following research question: (1) Can jigsaw technique improve the eighth graders' reading comprehension? (2) Are the students interested in learning reading comprehension through jigsaw technique? It is hoped that this action research as a way to solve those problems and will improve the eighth graders reading comprehension.

\section{Action Hypothesis}

In line with the research questions above, the action hypothesis of this research is stated as follow: "If Jigsaw technique is applied in teaching reading, students' reading comprehension will improve".

\section{Literature Review}

Reading is the process of receiving messages using eyes to see and interpret the meaning behind the symbols we call letters. Reading can be defined as an activity to understand something written. Goodman in Abisamra (as cited in Harland, 2013, p.2) affirmed that reading is a receptive language process. He said that there is an essential interaction between language and thought in reading. Reading is one of learning ways for students to enrich their ability and knowledge. In reading, the students are expected to be able to comprehend what they have read. It means that reading is an activity to understand the meaning of printed words. Nevertheless, when students read, actually they do interaction with the text. Reading is also defined as the skill or activity of getting information from books. So the more people read, the more they get information that contributes a great advantage in our life such as gaining success in school for student (Arini, 2013).

Reading is important to master by students. It is a way to get information from something that was written and it is part of important skill in language learning. The 
students can enhance their knowledge by reading and they can improve their performance in understanding the reading text as well. Due to its high importance, according to, (Pardede, 2008), reading seems to be the most extensively and intensively studied skills in the field of language teaching. Despite, reading is not only an activity to read a text but also an effective way to produce large-scale vocabulary growth (Harland, 2013). The reader get double advantages after reading a text not only catch the knowledge but also enrich their vocabulary.

Wooley (2011) argued that reading comprehension is the process of making meaning from text. The goal, therefore, is to gain an overall understanding of what is described in the text rather than to obtain meaning from isolated words or sentences. Reading comprehension must be developed by people who read a text. Without comprehending the text, they did not know what the writer talk about. Pardede (2007) pointed out that current theories view reading as a process of not just extracting meaning from a text but a process of connecting information in the text with the reader's knowledge he brings to the act of reading. Reading, in this sense, is "a dialogue between the reader and the text" (Grabe, 1988, p. 56). This is affirmed by Clarke, Truelove, Hulme, \& Snowling (2014) who noted that reading comprehension comes from the interaction between the text and the reader's response to it. It can therefore be concluded that reading comprehension is an activity to make connections between parts of the test in order to build up an interpretation requires recognition of the words, an ability to hold information in mind.

Jigsaw is a teaching technique invented in 1971 by Elliot Aronson, a social psychologist. Jigsaw is a teaching technique which allows the students to learn in groups by placing the students in desegregated groups and making each student dependent on other students in the group to learn the course materials (Aronson et al.2004 as cited in Hadisantosa 2009, p.224). Jigsaw is an efficient way to learn the course material in a cooperative learning style. The jigsaw process encourages listening, engagement, and empathy by giving each member of the group an essential part to play in the academic activity. Group members must work together as a team to accomplish a common goal; each person depends on all the others. No student can succeed completely unless everyone works well together as a team. This "cooperation by design" facilitates interaction among 
all students in the class, leading them to value each other as contributors to their common task (Schreyer Institute for Teaching Excelence, 2007).

Jigsaw technique like pieces of a jigsaw puzzle, the home groups break apart them the students move to expert group consisting of members from the other home groups who have been assigned the same portion of the material. In the expert group the students discuss their particular material to ensure that they understand it (Maden, 2011). These are steps identified by Aronson, 2008 (as cited ini Adams, 2013, p.7) they are: first, students are divided into 5 or 6 people's jigsaw group. The group should be diverse in terms of ethnicity, gender, ability and race. Second, one student should be appointed as the group leader. This person should initially be the most mature student in the group. Third, the day's lesson is divided into six to five segments (one for each member). Fourth, each student is assigned one segment to learn. Each student should only have direct access to their own segment. Fifth, students should be given time to read over their segment at least twice to become familiar with it. Students do not need to memorize it. Sixth, temporary experts groups should be formed in which one student from each jigsaw group joins other students assigned to the same segment. Students in this expert group should be given time to discuss the main points of their segment and rehearse the presentation they are going to make to their jigsaw group. Eighth, Students come back to their jigsaw group. Ninth, student present their segment to the group, other members are encouraged to ask question for clarification. Tenth, the teacher needs to float from group to group in other to observe the process. The last, an exercise on the material should be given at the end so students realize that the sessions are not just for fun and games but they really count.

Many studies on the use jigsaw technique to improve eighth graders' reading comprehension have been carried out. Most of them revealed that jigsaw technique significantly improve eighth graders' reading comprehension. Ayu Arini (2013) found students became active in learning activity, sometime they get difficult words in text, but they can ask their group members so the students can comprehend the text better. Yunus Purwowibowo (2013) in his research, he concluded that the implementation of jigsaw technique is effective to improve the students' reading comprehension. The researcher also found that jigsaw technique helped the students to understand the text easily through 
the discussion process and the presentation session. It also facilitates the students to make them eager to read the text by themselves.

\section{Methodology}

An action research design, i.e., "a principled way of observing one's teaching, reflecting upon it, and trying to analyze its weaknesses and increase its strengths. ... through which educators can help themselves and their students overcome the specific problems they encounter in the learning and teaching process" (Pardede, 2016, p.143) was employed in this study. It was conducted in a two cycles April to May 2016 in SMP 1 PSKD Kwini, Central Jakarta. The participants were the eighth graders, whose reading comprehension skill was categorized weak.

The data was collected using test and non-test techniques. The test technique was used to collect quantitative data derived from the students' reading comprehension achievement. Non-test techniques were used to collect qualitative data, including: observation, interview, and diary notes. Tests were carried out three times; the pre-test, post test I, and post test II. The non-test techniques were carried out using observation sheet, interview guide, and researcher's diary notes. To analyze the quantitative data obtained from the tests, the researcher analyzed by using statistic descriptive. To analyze the qualitative data, descriptive analysis technique was employed.

To guarantee the validity of the qualitative data obtained in this study, methodological, theoretical, and time triangulations were employed. The methodological triangulation was administered by using more than one method for data collection, i.e. observations, interviews, diary notes and tests. The theoretical triangulation was carried out by using more than one theoretical scheme in the interpretation of the phenomenon. The time triangulation was conducted by collecting data in different times (two cycles) and from different sources (the other researcher, observer, and tests). The success indicator used in this study was the criteria minimum achievement at SMP 1 PSKD i.e. the score of $\geq 70$.

\section{Findings}

In addition to the students' lack of reading comprehension, this action research conducted by the fact that most of the students had low in reading comprehension and 
based on the discussion with English teacher at SMP 1 PSKD, the student had low motivation and was not excited to follow the lesson. Their initial poor reading comprehension was reflected by the scores they achieved in the pre-test before conducted cycle 1 was carried out. (See table 1 below

Table 1:

Students' Pre-Test Score

\begin{tabular}{ccccc}
\hline No & Category & Score Range & Frequency & Percentage \\
\hline 1 & Excellent & $\geq 80$ & 0 & $0 \%$ \\
2 & Very Good & $70-79$ & 3 & $11.11 \%$ \\
3 & Good & $60-69$ & 8 & $29.63 \%$ \\
4 & Fair & $40-59$ & 8 & $29.63 \%$ \\
5 & Poor & $\leq 39$ & 8 & $29.63 \%$ \\
& & Total & 27 & $100 \%$ \\
\hline
\end{tabular}

This table shows only 3 students $(11.11 \%)$ had attained the criteria minimum achievement. There were twenty four students categorized in below criteria minimum achievement. The mean score of whole students in this pre-test was 49.03.

\section{Report of Cycle 1}

\section{Plan}

The first cycle was planned to overcome the problems during the initial observation and before jigsaw technique implement, i.e. (1) the students lack of motivation in learning reading (2) the students less participated in learning reading (3) the students were more talk active when teacher explained the lesson and (4) they were lazy to read because reading was less attractive in learning process in classroom. To solve the problems, the researcher planned to provide interesting learning atmosphere by using jigsaw technique.

\section{Action}

The actions of Cycle 1 were conducted in three meetings started on Monday, 18 th April, 2016, 19th April, 2016 and was ended on Monday, 25 th April, 2016. The texts used in these sessions were Cinderella, The Prince and His Best Friends, The Kind Man and The Sparrow, and Roro anteng and Jaka Seger text. The first meeting was started by 
introducing the jigsaw technique procedures. After that, the researcher assigned the students into group based on the role of jigsaw and distributed the text to each students. The researcher asked them to make home group and expert group. The students asked to discuss their segment only in the expert group. Finally, researcher evaluated the students by giving ten questions. The same procedure was done in the next meetings. After the three meeting done, the researcher conducted the post-test of Cycle 1

\section{Observing}

During the implementation of the actions in the first cycle, a colleague of the researcher was asked to observe the process, especially the students and also the researcher's activity. The observation sheet included the learning process, giving assignment, material, researcher's performance, technique implementation, class interaction. Table 2 below recapitulates the observation sheet in every meeting in Cycle 1. As shown by the table, the first meeting only $30 \%$ of the teaching activity was fulfilled by the researcher. However, the fulfillment increased to $65 \%$ in the second meeting and $70 \%$ in the third meeting. The percentage showed there was improvement of the teaching learning process from a session to the next.

Table 2:

Observation Result of Cycle 1

\begin{tabular}{|c|c|c|c|c|c|c|c|}
\hline \multirow[t]{2}{*}{ No } & \multirow[t]{2}{*}{ Focus and Topics } & \multicolumn{2}{|c|}{ Meeting 1} & \multicolumn{2}{|c|}{ Meeting 2} & \multicolumn{2}{|c|}{ Meeting 3} \\
\hline & & YES & NO & YES & NO & YES & NO \\
\hline 1 & Learning process & 1 & 3 & 3 & 1 & 3 & 1 \\
\hline 2 & Giving assessment & 0 & 2 & 2 & 0 & 2 & 0 \\
\hline 3 & Material & 2 & 1 & 2 & 1 & 2 & 1 \\
\hline \multirow[t]{2}{*}{4} & Researcher's & 2 & 3 & 2 & 3 & 3 & 2 \\
\hline & performance & & & & & & \\
\hline \multirow[t]{2}{*}{5} & Technique & 1 & 3 & 3 & 1 & 3 & 1 \\
\hline & Implementation & & & & & & \\
\hline \multirow[t]{3}{*}{6} & Class Interaction & 0 & 2 & 1 & 1 & 1 & 1 \\
\hline & Total & 6 & 14 & 13 & 7 & 14 & 6 \\
\hline & Percentage & $30 \%$ & $70 \%$ & $65 \%$ & $35 \%$ & $70 \%$ & $30 \%$ \\
\hline
\end{tabular}


In addition, the observer also found that the researcher lacked of self-confidence while opening the class and the students talked each other or made jokes with their friends. It is seen from the students' interest to pay attention to the researcher's explanations. The problems that occurred in Cycle 1 had to solve in the next cycle.

Based on the scores they obtained in post-test I, there were 11 students $(40.75 \%)$ of the 27 students who fulfilled the criteria minimum achievement and $16(48.14 \%)$ students needed to enhance their score. It proved that there were some improvements from the pretest mean score. It could be seen from the pre-test mean score (49.03) to the mean score of post-test Cycle 1 (65.78). (See table 3)

Table 3:

Students' Post-Test Score of Cycle 1

\begin{tabular}{ccccc}
\hline No & Category & Score Range & Frequency & Percentage \\
\hline 1 & Excellent & $\geq 80$ & 6 & $22.22 \%$ \\
2 & Very Good & $70-79$ & 5 & $18.52 \%$ \\
3 & Good & $60-69$ & 5 & $18.52 \%$ \\
4 & Fair & $40-59$ & 11 & $40.75 \%$ \\
5 & Poor & $\leq 39$ & 0 & $0 \%$ \\
& & 27 & $100 \%$ \\
\hline
\end{tabular}

The result of discussion Cycle 1 in improving students' reading comprehension through jigsaw technique was good. Nevertheless, there were still students who showed a negative attitude in the learning process. Based on the reflection result in this Cycle, the researcher continued to conduct the second cycle for achieving the optimal result.

\section{Reflecting}

The researcher reflected the result of the implementation of jigsaw technique and to see the result of post-test Cycle 1. The researcher considered some points based on the observation result analysis in this reflecting. The researcher reflected the result of posttest Cycle 1 and the weakness reported through the observation sheet. This reflection results were used as the basic for improving the action plan for Cycle 2. 


\section{Report of Cycle II}

\section{Plan}

Based on the reflection result in Cycle 1, in Cycle II, the researcher made a plan to provide more likely and interesting text. The researcher also would encourage them to be more active and participative in class activities. The researcher also designed lesson plan, preparing reading texts, preparing observation sheet for each meeting, and preparing the students' exercises in each meeting

\section{Action}

In Cycle 2, it consisted of three meetings which were held on May 16 th, 17th, and 23 rd 2016. In this action process, the researcher conducted the action based on the reflection in previous cycle. The texts used in these sessions were La Liorona The Crying Woman and The Old Grandfather and His Grandson text. The first meeting was started by explaining of narrative text as a kind of reading text used. In this session, the researcher conducted a game namely dor games as a warming up for the students. After that, the researcher assigned the students into group based on the role of jigsaw and distributed the text to each students. The researcher asked them to make home group and expert group. The students asked to discuss their segment only in the expert group. Finally, researcher evaluated the students by giving ten questions. The same procedure was done in the next meetings. After the three meeting done, the researcher conducted the post-test of Cycle 2.

Table 4:

Observation Results of Cycle II

\begin{tabular}{llcccccc}
\hline $\mathrm{N}$ & \multicolumn{1}{c}{ Focus and Topics } & \multicolumn{2}{c}{ Meeting 1 } & \multicolumn{2}{c}{ Meeting 2 } & \multicolumn{2}{c}{ Meeting 3 } \\
\cline { 3 - 7 } $\mathrm{o}$ & & YES & NO & YES & NO & YES & NO \\
1 & Learning process & 2 & 2 & 4 & 0 & 4 & 0 \\
2 & Giving assessment & 1 & 1 & 1 & 0 & 1 & 1 \\
3 & Material & 2 & 1 & 2 & 1 & 2 & 1 \\
4 & Researcher's performance & 5 & 0 & 5 & 1 & 5 & 0 \\
5 & Technique & 3 & 1 & 4 & 0 & 4 & 0 \\
& Implementation & & & & & & \\
6 & Class Interaction & 2 & 0 & 2 & 0 & 2 & 0 \\
& $\quad$ Total & 15 & 5 & 18 & 2 & 18 & 2 \\
& $\quad$ Percentage & $75 \%$ & $35 \%$ & $90 \%$ & $10 \%$ & $90 \%$ & $10 \%$ \\
\hline
\end{tabular}




\section{Observing}

Just like in Cycle I, during the implementation of the actions in the second cycle, a colleague helped the researcher to observe the process, especially the researcher and students activity. The result of observations in every meeting in Cycle II is recapitulated in Table 4

As shown in the table, it indicates in the first meeting only $75 \%$ of the teaching activity was fulfilled by the researcher. The fulfillment increased to $90 \%$ in the second meeting and $90 \%$ in the third meeting of Cycle 2. The observation results of Cycle 2 for improving students' reading comprehension through jigsaw technique shows the teaching and learning process in the class succeed. The researcher taught the students confidently, the students did not make jokes in the class, and they were interacted in group during learning process.

Table 5:

Recapitulation of Observation in Cycle I and Cycle II

\begin{tabular}{|c|c|c|c|}
\hline \multirow[t]{2}{*}{ No } & \multirow[t]{2}{*}{ Focus and Topics } & \multicolumn{2}{|c|}{ Meeting I-VI } \\
\hline & & YES & No \\
\hline 1 & Learning process & 17 & 7 \\
\hline 2 & Giving assessment & 7 & 4 \\
\hline 3 & Material & 12 & 6 \\
\hline 4 & Researcher's performance & 22 & 9 \\
\hline 5 & Technique Implementation & 18 & 6 \\
\hline 6 & Class Interaction & 8 & 4 \\
\hline & Total & 84 & 36 \\
\hline
\end{tabular}

As shown in table above, it indicates the recapitulation of observations in all meetings. All the result of observation was recapitulated from meeting I to meeting VI. The number of "YES" was fulfilled by the observer were $84(70 \%)$ while the number of "NO: was fulfilled by the observer were $36(30 \%)$. It means that the researcher had successful in teaching the students through the technique applied. 
Table 6:

\begin{tabular}{|c|c|c|c|c|c|}
\hline \multirow[t]{2}{*}{ No } & \multirow[t]{2}{*}{ Description } & \multicolumn{2}{|c|}{ YES } & \multicolumn{2}{|c|}{ NO } \\
\hline & & f & $\%$ & F & $\%$ \\
\hline 1 & $\begin{array}{l}\text { Students' feeling in learning } \\
\text { reading comprehension } \\
\text { through jigsaw technique }\end{array}$ & 6 & $100 \%$ & - & - \\
\hline 2 & $\begin{array}{l}\text { Students' experience in } \\
\text { overcome the difficulties in } \\
\text { learning reading } \\
\text { comprehension }\end{array}$ & 6 & $100 \%$ & - & - \\
\hline 3 & $\begin{array}{l}\text { Students' opinion in learning } \\
\text { reading comprehension } \\
\text { through jigsaw technique }\end{array}$ & 4 & $66.67 \%$ & 2 & $33.33 \%$ \\
\hline 4 & $\begin{array}{l}\text { Students' ability in } \\
\text { comprehending a text through } \\
\text { jigsaw technique }\end{array}$ & 4 & $66.67 \%$ & 2 & $33.33 \%$ \\
\hline 5 & $\begin{array}{l}\text { Students' opinion in } \\
\text { suggesting jigsaw technique } \\
\text { will be applied in learning } \\
\text { reading }\end{array}$ & 5 & $83.33 \%$ & 1 & $16.67 \%$ \\
\hline
\end{tabular}

As shown in the table above points out that all (100\%) interviewees feeling enjoy in learning reading comprehension through jigsaw technique and $(100 \%)$ have experience in overcome the difficulties in learning reading comprehension. However, 4 interviewees $(66.76 \%)$ gave positive opinion in learning reading comprehension through jigsaw technique while 2 interviewees did not gave their opinion. The same thing with the next description, two interviewees $(66.76 \%)$ were able comprehend reading text through jigsaw technique and $2(66.76 \%)$ interviewees did not gave their opinion. The last description of the table above was all (100\%) interviewees suggest that jigsaw technique will be applied in learning reading. 
Fransiska, Improving the Eight Graders' Reading Comprehension through Jigsaw

Table 7:

\begin{tabular}{ccccc}
\multicolumn{5}{l}{ Students' Post Test score of Cycle II } \\
\hline No & Category & Score Range & Frequency & Percentage \\
\hline 1 & Excellent & $\geq 80$ & 14 & $51.85 \%$ \\
2 & Very Good & $70-79$ & 5 & $18.52 \%$ \\
3 & Good & $60-69$ & 4 & $14.81 \%$ \\
4 & Fair & $40-59$ & 3 & $11.11 \%$ \\
5 & Poor & $\leq 39$ & 1 & $3.703 \%$ \\
& & & 27 & $100 \%$
\end{tabular}

As shown in the table above, it indicates that post-test cycle 2 results, 14 (51.85\%) of the students who achieved "excellent" category, five $(18.52 \%)$ of the students who achieved "very good" category, five (14.81\%) of the students who achieved "good" category, three $(11.11 \%)$ of the students who achieved "fair" category and one $(3.703 \%)$ of the students who achieved "poor" category. In this cycle, there were eight students who did not achieve the criteria minimum achievement. It happened because the students did not study seriously and sometimes they did not focus in learning process activity.

\section{Reflecting}

In reflection, the researcher analyzed the data was taken from test, observation, and researcher's diary notes. After the results of pre-test, post-test 1 in Cycle 1 and post-test 2 in Cycle 2 were combined to see an improvement the students in reading comprehension. The researcher reflected the result of the implementation of jigsaw technique and observation's result of learning Cycle 1.

\section{Hypothesis Test}

After the researcher distributed the test; pre-test, post-test Cycle 1 and post-test Cycle 2, the researcher analyzed it and got the result of each test. The mean score of pretest was 49.03, the mean score of post-test Cycle 1 was 65.78, and the mean score of posttest Cycle 2 was 75.85. This result proved there was an improvement during the treatments. It can conclude that the hypothesis is accepted which is stated that "if Jigsaw technique is applied in teaching reading, student' reading comprehension will improve" 


\section{Discussion}

Based on the identification of problems, it is known that the reading comprehension of eighth graders' at SMP 1 PSKD have been less before they study through jigsaw technique. It is shown from the pre-test result that the mean of students' score is 49.03 points. From the initial observation, the researcher identified that the students lacked of motivation in learning reading, they were difficult to answer questions based on the text and they did not know the meaning of the words. Post-test Cycle 1 was conducted in the next day of the third meeting of Cycle 1 finished. In first cycle shows that, the students' reading comprehension started increasing from pre-test before, there were $13(11.11 \%)$ students who achieved the standard of minimum score, which is $\geq 70$. While there were $11(40.74 \%)$ students who achieved the standard minimum score in post-test Cycle 1.

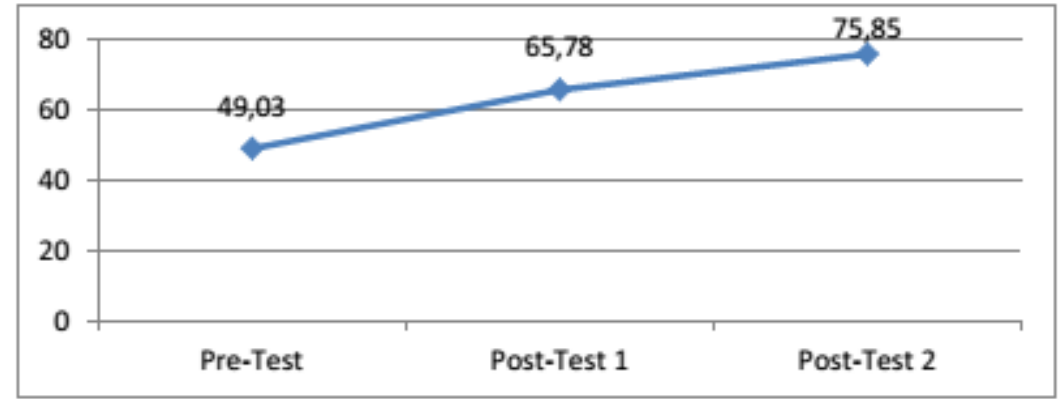

Chart 1: The Comparison of the Students Mean Score

The action on the first cycle needs to be improved through the second cycle. On the second cycle, the researcher applied jigsaw technique in teaching reading text. The researcher distributed text and asked the students to make group. Then, the students discussed the text. In addition, the researcher also explained the text by discussing with the students about the characters of the text and language features of the text. Then posttest Cycle 2 was conducted in the next day after the last meeting in Cycle 2. The result obtained in post-test Cycle 2 was 19 (70.37\%) students who achieved the standard of minimum score or a half of the number of students passed the post-test Cycle 2. There was a difference mean score from pre-test and posttest Cycle 1. The mean score of pretest was 49.03 while the mean of post-test Cycle 1 was 65.78 . The improvement score still found in the post-test Cycle 2. The mean of post-test Cycle 2 was 75.85. It can be computed the improvement score from the pre-test to post-test Cycle 2 was $54.70 \%$. According to Mauludi (2011), "Jigsaw technique can help students to communicate one another if they have problems in reading text"(p. 23). From the score appeared above, it 
can conclude that jigsaw technique successfully helped the students to comprehend reading text.

Before the application jigsaw technique, the mean score was only 49.03 points. Since treated through jigsaw technique in reading comprehension in Cycle 1, in post-test 1 mean score was 65.78 points. In Cycle 2, the students' mean score improved to 75.85 points. After learning reading comprehension through jigsaw technique in two cycles, the students' reading comprehension was improved.

\section{Conclusion}

Along with the improvement in class management, attention to every students and performance in the jigsaw technique, the students' enthusiasm and involvement kept on increasing from cycle to cycle. This increase of engagement then increased their achievement, as shown by the results of each test given by the researcher, which conducted at the end of every cycle. This indicates that jigsaw technique to improve eighth graders' reading comprehension is very effective.

\section{References}

Arini, A. (2013). Improving students' reading comprehension of narrative text through jigsaw technique (Unpublished undergraduate thesis). Jakarta: Syarif Hidayatullah State Islamic University. Retrieved from http://repository.uinjkt. ac.id/dspace/bitstream/ 123456789/24683/1/Ayu\%20Arini.pdf

Grabe, B. 1997. Discourse analysis and reading instruction. In Functional approaches to written text: Classroom applications, ed. T. Miller, 2-15. Washington, DC: United States Information Agency.

Harland, P. (2013). Teaching reading narrative text trough jigsaw technique at senior high school. Padang: University of Bung Hatta (Unpublished undergraduate thesis). Retrieved from http://ejurnal.bunghatta.ac.id/index.php?journal=JFKIP\&page $=$ article\&op=view $\&$ path $\% 5 \mathrm{~B} \% 5 \mathrm{D}=1877 \&$ path\%5B\%5D=1677

Maden, S. (2011). Effect of jigsaw I technique on achievement in written expression skill. Cumhuriyet University. (Unpublished undergraduate thesis). Retrieved from http://files.eric.ed.gov/fulltext/EJ927383.pdf 
Mauludi, M. Y. (2011). The effectveness of jigsaw technique to improve students' reading ability in narrative text (an experimental research at the eleventh grade of SMAN Kendal in the academic year 2010/2011. (Unpublished undergraduate thesis).Walisongo: State Institute for Islamic Studies. Retrieved from http://library.walisongo.ac.id/digilib/files/disk1/115/jtptiain-gdl-muhammadyu5717-1 -063411007.pdf

Pardede, P. (2016). Action Research in EFL Learning and Teaching. Paper presented in UKI's English Education Department Collegiate Forum held on Friday, December 9, 2016

Pardede, P. (2008). A review of reading theories and its implication to the teaching of reading. Retrieved from https://parlindunganpardede.wordpress.com/articles/language-teaching/areview-on-reading-theories-and-its-implication-to-the-teaching-of-reading/

Pardede, P. (2007). Developing critical reading in the EFL classroom. Retrieved November 2013 from http://parlindunganpardede.wordpress.com/articles/ language-teaching/developingcritical-reading-in-the-efl-classroom/

Pierce, J. (2015). Cooperative learning in classrooms today. Journal on Best Teaching Practices, 2.

Purwowibowo. (2015). Using jigsaw technique to improve reading comprehension of class VII of SMPN 2 Depok. Yogyakarta: Yogyakarta State University. (Unpublished undergraduate thesis). Retrieved from http://eprints.uny.ac.id/16136/1/Yunus\%20Purwowibowo\%2010202244031.pdf

Scharer, P. L. (2012). What is reading? The Ohio State University. Schmuck, R. A. (2009). Practical action research. California: Corwin Press.

Winten, K. (2013). Improving reading comprehension through jigsaw technique to the eight grade students of SMPN Satu Atap Jungutan in academic year 2012/2013. Denpasar: Mahasaraswati Denpasar University. (Unpublished undergraduate thesis). Retrieved from http://unmas-library.ac.id/wp-content/uploads/2014/06/fdfbnar-dek-win.pdf 